\title{
Adjuvant therapy in renal cell carcinoma: is it the right strategy to inhibit VEGF?
}

\author{
Veronica Mollica ${ }^{1}$, Alessandro Rizzo ${ }^{1}$, Vincenzo Di Nunno ${ }^{2}$, Matteo Santoni ${ }^{3}$, Liang Cheng ${ }^{4}$, \\ Antonio Lopez-Beltran ${ }^{5}$, Marina Scarpelli ${ }^{6}$, Alessia Cimadamore ${ }^{6}$, Rodolfo Montironi $^{6}$, Francesco Massari ${ }^{1}$ \\ ${ }^{1}$ Oncologia Medica, Azienda Ospedaliero-Universitaria di Bologna, Bologna, Italia; ${ }^{2}$ Department of Medical Oncology, Azienda USL of Bologna, \\ Bologna, Italy; ${ }^{3}$ Macerata Hospital, Macerata, Italy; ${ }^{4}$ Department of Pathology and Laboratory Medicine, Indiana University School of Medicine, \\ Indianapolis, IN, USA; ${ }^{5}$ Department of Surgery, Cordoba University Medical School, Cordoba, Spain; ${ }^{6}$ Section of Pathological Anatomy, Polytechnic \\ University of the Marche Region, School of Medicine, United Hospitals, Ancona, Italy \\ Contributions: (I) Conception and design: V Di Nunno, F Massari; (II) Administrative support: M Santoni, L Cheng, A Lopez-Beltran, M Scarpelli, \\ A Cimadamore, R Montironi; (III) Provision of study materials or patients: V Di Nunno, V Mollica, A Rizzo, F Massari; (IV) Collection and \\ assembly of data: V Di Nunno, V Mollica, A Rizzo, F Massari; (V) Data analysis and interpretation: V Di Nunno, V Mollica, A Rizzo, F Massari; (VI) \\ Manuscript writing: All authors; (VII) Final approval of manuscript: All authors. \\ Correspondence to: Francesco Massari, MD. Oncologia Medica, Azienda Ospedaliero-Universitaria di Bologna, Via Albertoni 15, Bologna, Italia. \\ Email: fmassari79@gmail.com.
}

\begin{abstract}
Despite several clinical trials have assessed different agents in the adjuvant setting, renal cell carcinoma (RCC) still remains a disease orphan of an effective adjuvant treatment. In fact, systemic therapies targeting angiogenesis that have been observed to be effective in metastatic setting failed to show an improvement in terms of clinical outcomes when used ad adjuvant treatments. In this study, we performed a meta-analysis of 5 randomized clinical trials to assess the impact of tyrosine kinase inhibitors (TKIs) targeting angiogenesis after surgery: ASSURE, S-TRAC, PROTECT, ATLAS, SORCE. Among the 6,531 patients assessed, we confirmed the lack of efficacy of adjuvant treatments in terms of diseasefree survival (DFS) (pooled-HR 0.93, 95\% CI, 0.84-1.02, P=0.16) and overall survival (OS) (pooled-HR $0.98,95 \% \mathrm{CI}, 0.88-1.09, \mathrm{P}=0.54)$. To the best of our knowledge, we still ignore why some treatments active in the metastatic setting do not show similar efficacy as adjuvant treatment. Exploring possible reasons of this apparently conflicting results is important as it may offer new insights that should be evaluated in next generation adjuvant trials. Immune checkpoint inhibitors (ICIs) have reported significant results-as monotherapy or in combinations with other anticancer agents-in metastatic setting, and the results of trials evaluating these agents in the adjuvant setting are awaited.
\end{abstract}

Keywords: Adjuvant therapy; disease-free survival (DFS); renal cell carcinoma (RCC); tyrosine kinase inhibitor (TKI)

Submitted Jul 28, 2020. Accepted for publication Oct 27, 2020.

doi: $10.21037 /$ tau-20-1125

View this article at: http://dx.doi.org/10.21037/tau-20-1125

\section{Introduction}

Renal cell carcinoma (RCC) represents the most commonly diagnosed kidney cancer worldwide, comprising the $4 \%$ of all solid tumours $(1,2)$. Radical surgical resection is the standard of care for patients with localized disease, and although the $70 \%$ of all RCC cases are diagnosed with early-stage or locally advanced disease, approximately the $20-40 \%$ of patients progress toward metastatic disease following radical surgery $(3,4)$. Recent years have witnessed remarkable changes in the therapeutic landscape of RCC, with the advent of several targeted agents and immune checkpoint inhibitors (ICIs), as single-agents or as part of immune-based combinations in the metastatic setting (5-8). 


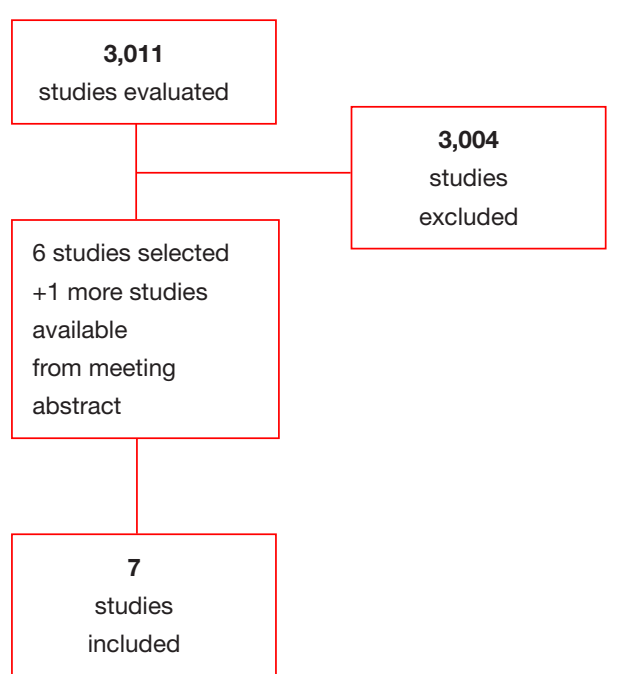

Figure 1 Diagram of all the trials included and excluded in the present meta-analysis.

Conversely, adjuvant treatment in RCC is still a problematic issue despite several adjuvant therapies have been tested in an attempt to improve clinical outcomes for RCC patients (9). Indeed, none of the compounds evaluated in this field have shown a convincing clinical benefit justifying an inclusion in clinical practice (10).

In this paper, we carried out a meta-analysis evaluating the impact of tyrosine kinase inhibitors (TKIs) targeting angiogenesis in the adjuvant setting of RCC. This represents the most updated analysis involving all published studies (11-18). We present the following article in accordance with the PRISMA reporting checklist (available at http://dx.doi.org/10.21037/tau-20-1125).

\section{Methods}

\section{Search strategies}

All phase III clinical trials published until 1 October 2019, evaluating clinical role of TKIs in RCC were retrieved by three different authors (VDN, VM and FM). Keywords used for searching on PubMed/Medline, Cochrane library, and Scopus, were: "Adjuvant" OR "post-operative" OR "peri-operative" AND "sunitinib" OR "pazopanib” OR "sorafenib" OR "pazopanib" OR "axitinib" OR "everolimus" OR "temsirolimus" OR "cabozantinib" OR "lenvatinib" OR "tivozanib" OR "TKI" OR "tyrosine kinase inhibitors" AND "Renal Cell Carcinoma" OR "RCC" OR "renal tumours" OR "renal carcinoma"; only papers published in peer-reviewed journals, and written in English language, were considered. Furthermore, proceedings of the main International Oncological and Urological meetings (American Society of Clinical Oncology, European Society of Medical Oncology, American Association for Cancer Research, European Association of Urology, and American Urological Association), were also searched from 2005 onwards for relevant abstracts. When more than one report was available describing results of the same trial, the most recent information (corresponding to a longer followup and/or a higher number of patients) was considered in the analysis. Studies selected from first analysis were then restricted to clinical trials and then reviewed by three authors (VDN, VM and FM) separately in three different times (Figure 1 and Table 1).

Aims of the meta-analysis were:

(I) To evaluate the correlation between adjuvant TKIs and overall survival (OS) in all patients. For this aim, phase III randomized clinical trials evaluating TKIs impact on OS were eligible.

(II) To evaluate the correlation between adjuvant TKIs and disease-free survival (DFS) in all patients. For this aim, phase III randomized clinical trials evaluating TKIs impact on DFS were eligible.

\section{Data extraction and synthesis}

The following data were extracted for each publication: (I) study; (II) stage; (III) percentages of patients with clear cell or non-clear cells tumours; (IV) risk staging system adopted; (V) experimental treatment and comparator arm; (VI) dosage of experimental drugs; (VII) percentage of patients who experienced dose reduction; (VIII) number of patients; (IX) OS and DFS outcome expressed as HR for patients treated with TKIs compared to placebo comparator arm.

In addition, we collected all risk staging system adopted specifying which were the categories of risk considered and the percentage of patients in each risk categories.

Three separate Authors (VDN, VM and FM) conducted the search and identification independently in different times.

\section{Statistical design}

Co-primary endpoints of the meta-analysis were OS and DFS in all patients. Meta-analysis was performed using the Review Manager (RevMan 5.3) software. Summary measure was HR with $95 \%$ CI for OS and DFS. HRs selected 
Table 1 Characteristics of the clinical trials included in the meta-analysis

\begin{tabular}{|c|c|c|c|c|c|c|c|}
\hline Study & Stage & $\mathrm{cc}(\mathrm{n} \%)$ & $\begin{array}{l}\text { ncc } \\
(\mathrm{n} \%)\end{array}$ & $\begin{array}{l}\text { Risk staging } \\
\text { system }\end{array}$ & \multicolumn{2}{|c|}{ Treatment experimental/control } & Duration of \\
\hline ASSURE & $\begin{array}{l}\mathrm{pT} 1 \mathrm{~b} \text { G3-4 N0 (or pNx } \\
\text { where clinically N0) M0, } \\
\text { to any T any G N + (fully } \\
\text { resected) M0 }\end{array}$ & $79 \%$ & $21 \%$ & UISS & $\begin{array}{l}\text { - Sunitinib } 50 \text { mg once daily, } \\
\text { 4-week on/2-week off } \\
\text { - Sorafenib } 400 \text { mg twice- } \\
\text { daily } \\
\text { Starting doses amended for } \\
\text { the first one or two cycles } \\
\text { - Sunitinib: } 37.5 \text { mg once } \\
\text { daily } \\
\text { - Sorafenib } 400 \text { mg once } \\
\text { daily }\end{array}$ & Placebo & 54 weeks \\
\hline ATLAS & $\begin{array}{l}\geq \mathrm{pT} 2 \text { and/or } \mathrm{N}+\mathrm{M} 0 \text {, any } \\
\text { Fuhrman grade, ECOG } \\
\text { PS } 0 / 1\end{array}$ & $100 \%$ & $0 \%$ & $\begin{array}{c}\text { TNM and } \\
\text { Fuhrman grade }\end{array}$ & Axitinib 5 mg twice-daily & Placebo & 3 years \\
\hline SORCE & $\begin{array}{l}\text { Patients with } \\
\text { 'Intermediate' or 'High' } \\
\text { risk per the Leibovich } \\
\text { score } 3 \text { to } 11\end{array}$ & $84 \%$ & $16 \%$ & Leibovich & $\begin{array}{l}\text { Sorafenib } 400 \text { mg twice-daily } \\
\text { for } 1 \text { year followed by } 2 \text { years } \\
\text { of placebo } \\
\text { Sorafenib } 400 \text { mg twice-daily } \\
\text { for } 3 \text { year }\end{array}$ & Placebo & 3 years \\
\hline
\end{tabular}

cc, clear cell; ncc, non clear cell; DFS, disease free survival; OS, overall survival; UISS, University of California Los Angeles Integrated Staging System; SSIGN, stage, size, grade and necrosis score; Exp., experimental.

for analysis were adjusted for the maximum number of covariates. We applied the inverse variance technique for the meta-analysis of the HRs. Statistical heterogeneity between studies was examined using the $\mathrm{c}^{2}$ test and the $\mathrm{I}^{2}$ statistic.

\section{Results}

Overall adjuvant treatments with angiogenesis inhibitors do not reflect a DFS and OS advantage compared to placebo.

Of 3,011 studies assessed for meta-analysis, 3,004 studies were excluded as non-pertinent article. Six published studies and 1 study published as meeting abstract were included in our analysis. Of interest, there were only randomized studies (see Appendix 1). Of the eligible studies, two trials contained three arms (two experimental arms and one control arm); for clearer presentation and for data analysis, we split the SORCE and the ASSURE trials as follows: ASSURE sorafenib; ASSURE sunitinib; SORCE 1 year; SORCE 3 years).

The two outcomes assessed in this meta-analysis were OS and DFS.

Six trials provided OS data on patients receiving TKIs as adjuvant treatment versus placebo. According to the results of our analysis, a pooled OS-hazard ratio (HR) of 0.98 was observed (95\% CI, 0.88-1.09, $\mathrm{I}^{2}=0 \%, \mathrm{P}=0.54$ ) (Figure 2). The results showed low heterogeneity; therefore, a fixed effects model was used.

Seven trials provided DSF results regarding RCC patients treated with experimental treatment versus placebo; a pooled DFS-HR of 0.93 was obtained (95\% CI, $0.84-1.02, \mathrm{I}^{2}=35 \%, \mathrm{P}=0.16$ ) (Figure 3). Low heterogeneity was observed in this analysis, and thus, a fixed effects model as used. 


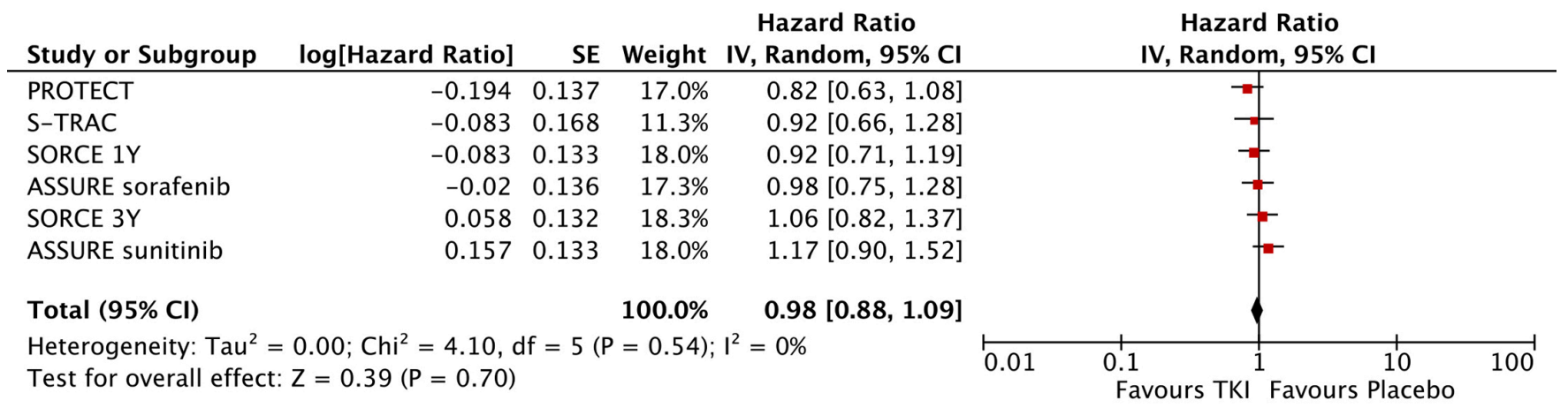

Figure 2 Forest plot of overall survival analysis.

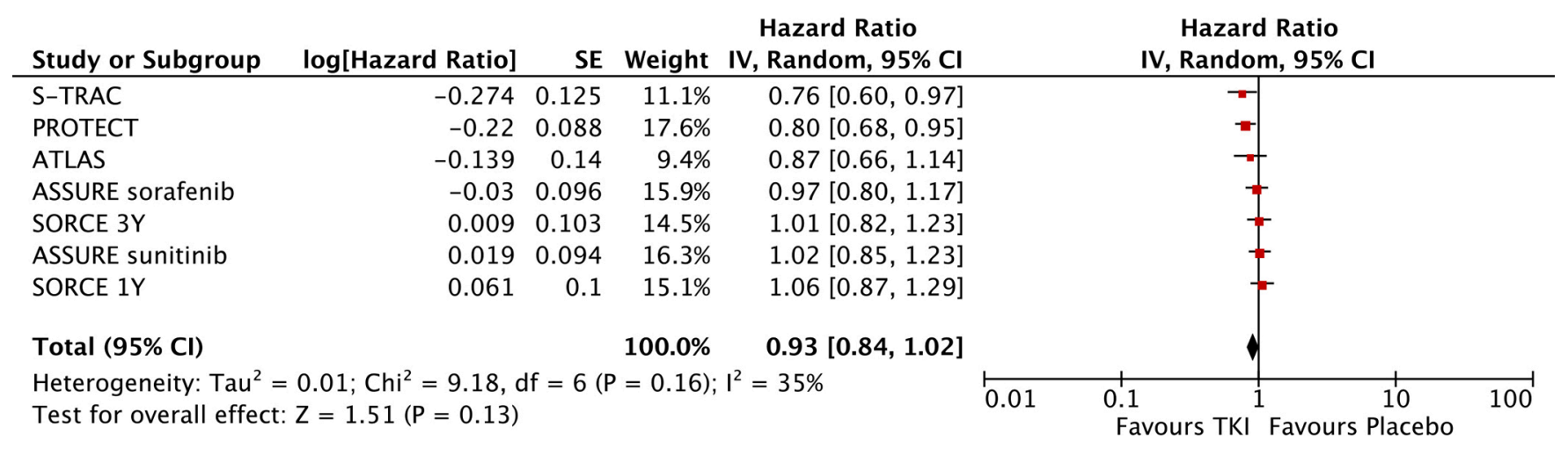

Figure 3 Forest plot of disease-free survival analysis.

\section{Discussion}

Adjuvant therapy in RCC is a challenging scenario for medical oncologists, with no data that could support offering adjuvant treatment in resected RCC outside of clinical trials. Our analysis confirms the known lack of efficacy of TKIs targeting angiogenesis in the adjuvant setting, which is reinforced by the assessment of 5 randomized clinical trials. In particular, the current metaanalysis does not reveal a statistically significant association between adjuvant TKIs targeting angiogenesis and improved DSF or OS in RCC patients.

As regard the included trials, SORCE, S-TRAC, ASSURE, PROTECT and ATLAS (Table 1) represent a second generation of adjuvant clinical studies which came after a first generation of trials exploring old immunecompounds such as interferon-alpha and interleukin-2 (12-18). In addition, the EVEREST trial is currently evaluating the mTOR inhibitor everolimus in adjuvant setting and results are still unavailable.
As expected, the upgraded results of our analysis seem not to differ from what observed in our precedent paper (11). Moreover, no particular subgroups of patients seem to benefit from angiogenesis inhibitors. However, to the best of our knowledge this is the most upgraded and complete meta-analysis involving all second-generation studies regarding TKIs targeting angiogenesis as adjuvant treatment in RCC. Summarizing results and pooling the results observed could be important to provide complete data and reinforce the evidence that inhibition of angiogenesis is useless in early phase of the disease; to date, a third generation of studies is evaluating the role of immune-checkpoint inhibitors in adjuvant setting and the results of these studies are highly awaited.

The reasons that may have brought to the failure of these second-generation trials should be carefully evaluated to avoid important mistakes in future trials planning. Addiction of TKIs after surgery on primary tumour do not result in DFS and OS benefit and, to the best of our knowledge, 
it is still unclear if this could be due to a missing effect of angiogenesis in early phases of metastasis development or to a lack of adequate patients' selection.

Of note, some issues should be discussed. Firstly, it should be mentioned that results of PROTECT trial may have been affected by a not negligible number of patients under-dosed. Indeed, no correlation between prescribeddoses and plasma-dose has been found (19). Second, angiogenesis inhibitors may not be able to act on early phases of metastatic disease; this hypothesis is further corroborated by the fact that neither TKIs targeting VEGFR nor VEGF have shown to be effective in the adjuvant setting of several malignancies. Besides, the results of our meta-analysis seem to confirm this hypothesis.

As known, several studies assessing the combination of PD-1/PD-L1 inhibitors and targeted therapies have been recently published or presented $(7,8)$. In metastatic setting, the CheckMate214, the KEYNOTE-426 and the JAVELIN Renal 101 have shown important clinical benefits compared to sunitinib alone, shaping the-novel - outlook of firstline setting. In addition, new data presented at ESMO 2020 have recently suggested that another immune-based combination, nivolumab plus cabozantinib, could represent a novel front-line treatment option for patients with metastatic RCC. In fact, the Checkmate 9ER has provided interesting results regarding this combination, which has been shown to be superior to sunitinib in terms of PFS, OS and response rate. These findings add to mounting evidence reporting the advantages of combination therapies (often including an angiogenesis inhibitor) over TKI monotherapy as first-line treatment in metastatic RCC.

Interestingly, despite an effective role of antiangiogenic drugs in metastatic disease (as monotherapy or in combination with other anticancer agents), the design of trials exploring these combinations in the adjuvant setting should consider that the addiction of angiogenesis inhibitors-according to currently available data-could only result in unnecessary toxicity without significant clinical benefit.

Importantly, selection of patients is still an important issue in adjuvant setting. In fact, a mandatory aspect of adjuvant therapy is certainly to select patients who are at increased risk of disease recurrence and to spare low-risk RCC patients from toxicity of adjuvant therapies. Of note, all studies considered in our analysis adopted different selection modalities with a not negligible heterogeneity in terms of tumour stages, risk of recurrence and tumour subtypes included. In fact, the S-TRAC trial enrolled a higher-risk population and the study protocol had important restrictions on histologic subtypes compared with ASSURE, something that could have played an important role in the highest DFS benefit observed in S-TRAC $(9,10)$. More specifically, one-third of patients of the ASSURE trial had low-risk tumours-pT1 and pT2 — and the ATLAS and the PROTECT studies included an important proportion of these patients (11\% and 14\%, respectively). Conversely, the S-TRAC study only enrolled patients affected by high risk tumours ( $\geq$ pT3). This issue raises an extremely important question in this setting: the DFS improvement in this trialas previously stated-could be related to the enrollment of patients that were at higher risk of recurrence.

As reported, a positive DFS trend may exist in patients with high risk of relapse treated with angiogenesis inhibitors in adjuvant setting. However, the best score to evaluate risk of recurrence is far from being standardized and none of the included studies evaluated genomic assessment of tumours samples. The correlation between genomic expression and risk of recurrence/clinical aggressiveness is a discussed but not completely explored issue (19), and to date, only one study validated a genomic assessment in the adjuvant setting (20). It is possible that currently adopted systems of risk assessment are not able to discern which patients are more likely to benefit from adjuvant treatment, thus we hope that the "next generation" of trials will provide new insights on this issue.

Despite several agents have been tested in the adjuvant setting, none of them showed a clear benefit in terms of OS and DFS. S-TRAC was the only trial in which a DFS advantage emerged; however, sunitinib is not administered in clinical practice as postoperative treatment since these results have not been mirrored in OS analysis. Considering all the results provided by clinical trials exploring TKIs in adjuvant setting, it appears clear that early inhibition of angiogenesis did not result in a clinical benefit. Thus, angiogenesis seems to be a survival strategy adopted in late phases of tumour evolution after metastases implantation.

As previously reported, immune-checkpoint inhibitors represent a concrete hope as postoperative treatments. In fact, ICIs achieved important clinical results in advanced setting of the disease and represent also a standard adjuvant treatment in other solid tumours such as melanoma $(21,22)$. However, it should be noted that immunotherapy alone seems to be more effective in patients with poorest clinical features, as suggested by the results of recently published landmark clinical trials in metastatic disease (23). Considering these issues, it cannot be excluded 
Table 2 Ongoing clinical trials exploring immune-checkpoint inhibitors as adjuvant therapies in renal cell carcinoma

\begin{tabular}{llll}
\hline Trial & Comparator & Experimental & Primary outcome \\
\hline IMmotion 010 & Placebo & Atezolizumab & DFS assessed by IR \\
CheckMate 914 & Placebo & Nivolumab + Ipilimumab & DFS assessed by IR \\
KEYNOTE -564 & Placebo & Pembrolizumab & DFS \\
NCT03055013 & Surgery & Nivolumab before Surgery & DFS \\
\hline
\end{tabular}

DFS, disease-free survival; IR, independent review.

that immune-checkpoint inhibitors could provide important results in the early setting of RCC. If this will be confirmed, the selection of the optimal candidates to adjuvant immunecheckpoint inhibitors will be another important issue to consider (24,25), and for example, patients with more aggressive disease (e.g., RCC with sarcomatous features) could be optimal candidate (26). More uncertain is the role of other combinations involving a PD-1/PD-L1 inhibitor and a TKI targeting VEGFR. As observed, TKIs are not associated with consistent improvements in delaying cancer recurrence or prolonging life when adopted in early setting and it seems unlikely that this could change when these agents are administered in combination with immune-checkpoint inhibitors. Ongoing trials will provide further information regarding the effective potential of these combinations, trying to translate in this setting the remarkable results recently observed in metastatic disease.

\section{Conclusions}

We assessed the overall effect of TKIs in adjuvant setting in kidney cancer, where the administration of these agentsaccording to our analysis-does not provide a DFS and OS benefit. A new wave of studies in adjuvant setting is in progress and their results could offer novel insights about adjuvant treatment in RCC (Table 2).

\section{Acknowledgments}

Funding: None.

\section{Footnote}

Reporting Checklist: The authors have completed the PRISMA reporting checklist. Available at http://dx.doi.org/10.21037/ tau-20-1125
Peer Review File: Available at http://dx.doi.org/10.21037/tau20-1125

Provenance and Peer Review: This article was commissioned by the editorial office, Translational Andrology and Urology for the series "Update on Molecular Classification and Individualized Treatments of Genitourinary Tumors". The article has undergone external peer review.

Conflicts of Interest: All authors have completed the ICMJE uniform disclosure form (available at http://dx.doi. org/10.21037/tau-20-1125). The series "Update on Molecular Classification and Individualized Treatments of Genitourinary Tumors" was commissioned by the editorial office without any funding or sponsorship. LC, ALB, MS, $\mathrm{AC}$ and RM served as the unpaid Guest Editors of the series. LC serves as an unpaid editorial board member of Translational Andrology and Urology from Dec 2018 to Nov 2022. The authors have no other conflicts of interest to declare.

Ethical Statement: The authors are accountable for all aspects of the work in ensuring that questions related to the accuracy or integrity of any part of the work are appropriately investigated and resolved.

Open Access Statement: This is an Open Access article distributed in accordance with the Creative Commons Attribution-NonCommercial-NoDerivs 4.0 International License (CC BY-NC-ND 4.0), which permits the noncommercial replication and distribution of the article with the strict proviso that no changes or edits are made and the original work is properly cited (including links to both the formal publication through the relevant DOI and the license). See: https://creativecommons.org/ licenses/by-nc-nd/4.0/. 


\section{References}

1. Siegel RL, Miller KD, Jemal A. Cancer statistics, 2019. CA Cancer J Clin 2019;69:7-34.

2. Hsieh JJ, Purdue MP, Signoretti S, et al. Renal cell carcinoma. Nat Rev Dis Primers 2017;3:17009.

3. Capitanio U, Montorsi F. Renal cancer. Lancet 2016;387:894-906.

4. Williamson SR, Taneja K, Cheng L. Renal cell carcinoma staging: pitfalls, challenges, and updates. Histopathology 2019;74:18-30.

5. Santoni M, Massari F, Di Nunno V, et al. Immunotherapy in renal cell carcinoma: latest evidence and clinical implications. Drugs Context 2018;7:212528.

6. Choueiri TK, Motzer RJ. Systemic therapy for metastatic renal- cell carcinoma. N Engl J Med 2017;376:354-66.

7. Calvo E, Porta C, Grunwald V, et al. The current and evolving landscape of first-line treatments for advanced renal cell carcinoma. Oncologist 2019;24:338-48.

8. Massari F, Mollica V, Rizzo A, et al. Safety evaluation of immune-based combinations in patients with advanced renal cell carcinoma: a systematic review and metaanalysis. Expert Opin Drug Saf 2020;19:1329-38.

9. Meissner MA, McCormick BZ, Karam JA, et al. Adjuvant therapy for advanced renal cell carcinoma. Expert Rev Anticancer Ther 2018;18:663-71.

10. Wood E, Donin N, Shuch B. Adjuvant Therapy for Localized High-Risk Renal Cell Carcinoma. Urol Clin North Am 2020;47:345-58.

11. Massari F, Di Nunno V, Mollica V, et al. Adjuvant Tyrosine Kinase Inhibitors in Treatment of Renal Cell Carcinoma: A Meta-Analysis of Available Clinical Trials. Clin Genitourin Cancer 2019;17:e339-44.

12. Ravaud A, Motzer RJ, Pandha HS, et al. Adjuvant Sunitinib in High-Risk Renal-Cell Carcinoma after Nephrectomy. N Engl J Med 2016;375:2246-54.

13. Motzer RJ, Ravaud A, Patard JJ, et al. Adjuvant Sunitinib for High-risk Renal Cell Carcinoma After Nephrectomy: Subgroup Analyses and Updated Overall Survival Results. Eur Urol 2018;73:62-8.

14. Motzer RJ, Haas NB, Donskov F, et al. Randomized Phase III Trial of Adjuvant Pazopanib Versus Placebo After Nephrectomy in Patients With Localized or Locally Advanced Renal Cell Carcinoma. J Clin Oncol 2017;35:3916-23.

15. Haas NB, Manola J, Uzzo RG, et al. Adjuvant sunitinib or sorafenib for high-risk, non-metastatic renal-cell carcinoma (ECOG-ACRIN E2805): a double-blind, placebo-controlled, randomised, phase 3 trial. Lancet 2016;387:2008-16.

16. Haas NB, Manola J, Dutcher JP, et al. Adjuvant Treatment for High-Risk Clear Cell Renal Cancer: Updated Results of a High-Risk Subset of the ASSURE Randomized Trial. JAMA Oncol 2017;3:1249-52.

17. Gross-Goupil M, Kwon TG, Eto M, et al. Axitinib Versus Placebo as an Adjuvant Treatment for Renal Cell Carcinoma: Results From the Phase III, Randomized ATLAS Trial. Ann Oncol 2018;29:2371-8.

18. Eisen TQG, Frangou E, Smith B, et al. Primary Efficacy analysis results from the SORCE trial (RE05): Adjuvant sorafenib for renal cell carcinoma at intermediate or high risk of relapse. Ann Oncol 2019;30:v851-v934.

19. Sternberg CN, Donskov F, Haas NB, et al. Pazopanib Exposure Relationship with Clinical Efficacy and Safety in the Adjuvant Treatment of Advanced Renal Cell Carcinoma. Clin Cancer Res 2018;24:3005-13.

20. Motzer RJ, Escudier B, McDermott DF, et al. Nivolumab versus Everolimus in Advanced Renal-Cell Carcinoma. N Engl J Med 2015;373:1803-13.

21. Motzer RJ, Penkov K, Haanen J, et al. Avelumab plus Axitinib versus Sunitinib for Advanced Renal-Cell Carcinoma. N Engl J Med 2019;380:1103-15.

22. Weber J, Mandala M, Del Vecchio M, et al. Adjuvant Nivolumab versus Ipilimumab in Resected Stage III or IV Melanoma. N Engl J Med 2017;377:1824-35.

23. Motzer RJ, Tannir NM, McDermott DF, et al. Nivolumab plus Ipilimumab versus Sunitinib in Advanced Renal-Cell Carcinoma. N Engl J Med 2018;378:1277-90.

24. Rini B, Goddard A, Knezevic D, et al. A 16-gene assay to predict recurrence after surgery in localised renal cell carcinoma: development and validation studies. Lancet Oncol 2015;16:676-85.

25. Rini BI, Escudier B, Martini JF, et al. Validation of the 16Gene Recurrence Score in Patients with Locoregional, High-Risk Renal Cell Carcinoma from a Phase III Trial of Adjuvant Sunitinib. Clin Cancer Res 2018;24:4407-15.

26. Mouallem NE, Smith SC, Paul AK. Sarcomatoid renal cell carcinoma: Biology and treatment advances. Urol Oncol 2018;36:265-71.

Cite this article as: Mollica V, Rizzo A, Di Nunno V, Santoni M, Cheng L, Lopez-Beltran A, Scarpelli M, Cimadamore A, Montironi R, Massari F. Adjuvant therapy in renal cell carcinoma: is it the right strategy to inhibit VEGF? Transl Androl Urol 2021;10(3):1581-1587. doi: 10.21037/tau-20-1125 
Table 1 Characteristics of the clinical trials included in the meta-analysis. References of included studies refer to the Bibliography of the manuscript. Abbreviations: $\mathrm{cc}=\mathrm{clear}$ cell; $\mathrm{ncc}=$ non clear

\begin{tabular}{|c|c|c|c|c|c|c|c|c|c|c|c|c|c|}
\hline \multirow{4}{*}{$\begin{array}{l}\text { Study } \\
\\
\text { ASSURE } \\
\text { (Haas) } \\
\text { (16) }\end{array}$} & \multirow{4}{*}{$\begin{array}{l}\text { Stage } \\
\text { pTlb G3-4 } \\
\text { N0 (or pNx } \\
\text { where } \\
\text { clinically N0) } \\
\text { M0, to any T } \\
\text { any G N + } \\
\text { (fully } \\
\text { resected) M0 }\end{array}$} & \multicolumn{2}{|c|}{$\begin{array}{l}\text { ce }(\mathrm{n} \%) / \text { nec } \\
(\mathrm{n} \%)\end{array}$} & \multirow{4}{*}{\begin{tabular}{l|}
$\begin{array}{l}\text { Risk } \\
\text { staging } \\
\text { system }\end{array}$ \\
UISS \\
\end{tabular}} & \multicolumn{2}{|l|}{$\begin{array}{l}\text { Treatment } \\
\text { Experimental/control }\end{array}$} & \multirow{4}{*}{\begin{tabular}{|l|}
$\begin{array}{l}\text { Duration of } \\
\text { treatment }\end{array}$ \\
54 weeks \\
\end{tabular}} & \multirow{2}{*}{\multicolumn{2}{|c|}{$\begin{array}{l}\text { Dose reduction } \\
\\
\text { Started at reduced } \\
\text { doses: } \\
\text { - Sunitinib/placebo: } \\
\text { 380/1294 patients } \\
\text { - Sorafenib/placebo: } \\
378 / 1296\end{array}$}} & \multirow{2}{*}{$\begin{array}{l}\text { Patients n } \\
\text { treatment } \\
\text { group / n } \\
\text { tot }\end{array}$} & \multirow{2}{*}{$\begin{array}{l}\text { Median } \\
\text { DFS (yr) }\end{array}$} & \multirow{2}{*}{$\begin{array}{l}\begin{array}{l}\text { Median } \\
\text { OS (yr) }\end{array} \\
\begin{array}{l}\text { Not } \\
\text { reached }\end{array}\end{array}$} & \multirow{2}{*}{$\begin{array}{l}\begin{array}{l}\text { Most common } \\
\text { adverse } \\
\text { events } Z \\
\text { grade 3) }\end{array} \\
\text { Hypertension } \\
(17 \%) \\
\text { Hand-foot } \\
\text { syndrome } \\
(15 \%) \\
\text { Rash }(2 \%)\end{array}$} \\
\hline & & $79 \%$ & $21 \%$ & & 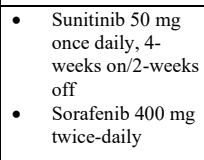 & Placebo & & & & & & & \\
\hline & & & & & $\begin{array}{l}\text { Starting doses } \\
\text { amended for the first } \\
\text { one or two cycles } \\
\text { - Sunitinib: } 37,5 \\
\text { mg once daily } \\
\text { - Sorafenib } 400 \mathrm{mg}\end{array}$ & & & & $\begin{array}{l}\text { Exp. } \\
\text { Sorafenib }\end{array}$ & $649 / 1943$ & 6.1 & $\begin{array}{l}\text { Not } \\
\text { reached }\end{array}$ & $\begin{array}{l}\text { Hypertension } \\
(16 \%) \\
\text { Hand-foot } \\
\text { syndrome } \\
(33 \%) \\
\text { Rash (15\%) }\end{array}$ \\
\hline & & & & & & & & & Control & $647 / 1943$ & 6.6 & $\begin{array}{l}\text { Not } \\
\text { reached }\end{array}$ & $\begin{array}{l}\text { Hypertension } \\
(4 \%) \\
\text { Hand-foot } \\
\text { syndrome } \\
(1 \%) \\
\text { Rash (1\%) }\end{array}$ \\
\hline \multirow[t]{2}{*}{$\begin{array}{l}\text { S-TRAC } \\
\text { (Ravaud) } \\
\text { (12) }\end{array}$} & \multirow[t]{2}{*}{$\begin{array}{l}\mathrm{T} 3 \text { or T4 and } \\
\mathrm{N} 0 \text { or Nx M0, } \\
\text { or any T and } \\
\mathrm{N}+\mathrm{M} 0\end{array}$} & \multirow[t]{2}{*}{$100 \%$} & \multirow[t]{2}{*}{$0 \%$} & \multirow[t]{2}{*}{ UISS } & \multirow[t]{2}{*}{$\begin{array}{l}\text { Sunitinib } 50 \mathrm{mg} \text { once } \\
\text { daily, } 4 \text {-weeks on/2- } \\
\text { weeks off }\end{array}$} & \multirow[t]{2}{*}{ Placebo } & \multirow[t]{2}{*}{1 year } & \multirow[t]{2}{*}{$\begin{array}{l}\text { Dose reduction to } 37,5 \\
\text { mg once daily in the } \\
\text { sunitinib group: } 34.3 \%\end{array}$} & Exp. & $309 / 615$ & 6.8 & $\begin{array}{l}\text { Not } \\
\text { reached }\end{array}$ & $\begin{array}{l}\text { Palmar-plantar } \\
\text { erythrodysesth } \\
\text { esia }(16 \%) \\
\text { Hypertension } \\
(7.8 \%) \\
\text { Neutropenia } \\
(7.5 \%)\end{array}$ \\
\hline & & & & & & & & & Control & $306 / 615$ & 5.6 & $\begin{array}{l}\text { Not } \\
\text { reached }\end{array}$ & $\begin{array}{l}\text { Palmar-plantar } \\
\text { erythrodysesth } \\
\text { esia }(0.3 \%) \\
\text { Hypertension } \\
(1.3 \%)\end{array}$ \\
\hline \multirow[t]{3}{*}{$\begin{array}{l}\text { PROTECT } \\
\text { (Motzer) } \\
\text { (14) }\end{array}$} & \multirow{3}{*}{$\begin{array}{l}\text { pT2 G3-4 N0 } \\
\text { M0, pT3-T4 } \\
\text { any G N0 M0, } \\
\text { or any pT any } \\
\text { G N1 M0 }\end{array}$} & \multirow[t]{3}{*}{$100 \%$} & \multirow[t]{3}{*}{$0 \%$} & \multirow[t]{3}{*}{ SSIGN } & \multirow{3}{*}{$\begin{array}{l}\text { Pazopanib } 800 \mathrm{mg} \\
\text { once daily } \\
\text { Starting dose amended } \\
\text { to } 600 \mathrm{mg} \text { once daily }\end{array}$} & \multirow[t]{3}{*}{ Placebo } & \multirow[t]{3}{*}{1 year } & \multirow{3}{*}{$\begin{array}{l}\text { Dose reduction in } \\
\text { pazopanib } 800 \mathrm{mg}: 60 \% \\
\text { Dose reduction in } \\
\text { pazopanib } 600 \mathrm{mg}: 51 \%\end{array}$} & Exp. & $\begin{array}{l}800 \mathrm{mg}: \\
\text { 198/1538 } \\
600 \mathrm{mg}: \\
571 / 1538\end{array}$ & \multirow[t]{2}{*}{\begin{tabular}{|l|} 
ITT $_{\text {ALL }}$ \\
not \\
reported
\end{tabular}} & \multirow[t]{2}{*}{$\begin{array}{l}\text { Not } \\
\text { reported }\end{array}$} & \multirow[t]{2}{*}{$\begin{array}{l}\text { Hypertension } \\
(25 \%) \\
\text { Increased ALT } \\
(16 \%) \\
\text { Diarrhea (7\%) }\end{array}$} \\
\hline & & & & & & & & & & $\begin{array}{l}\text { ITT }_{\text {ALL }} \\
(800+600 \\
\text { mg): } \\
769 / 1538\end{array}$ & & & \\
\hline & & & & & & & & & Control & $769 / 1538$ & $\begin{array}{l}\text { ITT }_{\text {ALL }} \\
\text { not } \\
\text { reported }\end{array}$ & $\begin{array}{l}\text { Not } \\
\text { reported }\end{array}$ & $\begin{array}{l}\begin{array}{l}\text { Hypertension } \\
(7 \%)\end{array} \\
\text { Increased ALT } \\
(1 \%) \\
\text { Diarrhea (1\%) }\end{array}$ \\
\hline \multirow[t]{2}{*}{$\begin{array}{l}\text { ATLAS } \\
\text { (Gross- } \\
\text { Goupil) } \\
\text { (17) }\end{array}$} & \multirow[t]{2}{*}{$\begin{array}{l}\geq \mathrm{pT} 2 \text { and/or } \\
\mathrm{N}+\mathrm{M} 0 \text {, any } \\
\text { Fuhrman } \\
\text { grade, ECOG } \\
\text { PS } 0 / 1\end{array}$} & \multirow[t]{2}{*}{$100 \%$} & $0 \%$ & $\begin{array}{l}\text { TNM and } \\
\text { Fuhrman } \\
\text { grade }\end{array}$ & $\begin{array}{l}\text { Axitinib } 5 \mathrm{mg} \text { twice- } \\
\text { daily }\end{array}$ & Placebo & 3 years & $\begin{array}{l}\text { Dose reduction in the } \\
\text { axitinib group: } 56 \%\end{array}$ & Exp. & $363 / 724$ & $\begin{array}{l}\text { Not } \\
\text { reported }\end{array}$ & $\begin{array}{l}\text { Not } \\
\text { mature }\end{array}$ & $\begin{array}{l}\text { Treatment- } \\
\text { related grade } \\
3-4 \text { adverse } \\
\text { events }(49 \%)\end{array}$ \\
\hline & & & & & & & & & Control & $361 / 724$ & $\begin{array}{l}\text { Not } \\
\text { reported }\end{array}$ & $\begin{array}{l}\text { Not } \\
\text { mature }\end{array}$ & $\begin{array}{l}\text { Treatment- } \\
\text { related grade } \\
3-4 \text { adverse } \\
\text { events }(12 \%)\end{array}$ \\
\hline $\begin{array}{l}\text { SORCE } \\
\text { (Eisen) } \\
\text { (18) }\end{array}$ & $\begin{array}{l}\text { Leibovich } \\
\text { score }(3-11)\end{array}$ & $84 \%$ & $16 \%$ & $\begin{array}{l}\text { Leibovich } \\
\text { score (3- } \\
11)\end{array}$ & $\begin{array}{l}\text { Sorafenib } 1 \text { year or } \\
\text { sorafenib } 3 \text { year ( } 400 \\
\text { mg daily starting dose. } \\
400 \mathrm{mg} \text { bd maximum } \\
\text { dose) }\end{array}$ & Placebo & 1 or 3 years & $\begin{array}{l}400 \mathrm{mg} \text { daily starting } \\
\text { dose. Increase of dose } \\
\text { up to } 800 \mathrm{mg} \text { in patients } \\
\text { without or with low } \\
\text { toxicity. } 200 \mathrm{mg} \text { daily } \\
\text { minimum dose }\end{array}$ & $\begin{array}{l}\text { Exp 1 } \\
\mathrm{Y}\end{array}$ & $642 / 1711$ & $\begin{array}{l}\text { 5 Y DFS } \\
67 \%\end{array}$ & $\begin{array}{l}10 \text { Y OS } \\
69 \%\end{array}$ & $\begin{array}{l}\text { Hypertension } \\
(26 \%) \\
\text { Hand-foot skin } \\
\text { reaction }(24 \%) \\
\text { Rash }(7 \%)\end{array}$ \\
\hline & & & & & & & & & Control & $430 / 1711$ & $\begin{array}{l}\text { 5 Y DFS } \\
67 \%\end{array}$ & $\begin{array}{l}10 \text { Y OS } \\
70 \%\end{array}$ & $\begin{array}{l}\text { Hypertension } \\
(20 \%)\end{array}$ \\
\hline & & & & & & & & & Exp $3 y$ & $639 / 1711$ & $\begin{array}{l}\text { 5Y DFS } \\
65 \%\end{array}$ & $\begin{array}{l}10 \text { Y OS } \\
69 \%\end{array}$ & $\begin{array}{l}\text { Hypertension } \\
(24 \%) \\
\text { Hand-foot skin } \\
\text { reaction }(24 \%) \\
\text { Rash }(10 \%)\end{array}$ \\
\hline & & & & & & & & & Control & $430 / 1711$ & $\begin{array}{l}5 \text { Y DFS } \\
67 \%\end{array}$ & $\begin{array}{l}10 \text { Y OS } \\
70 \%\end{array}$ & $\begin{array}{l}\text { Hypertension } \\
(20 \%)\end{array}$ \\
\hline
\end{tabular}




\section{METHODS}

\section{Search strategies}

All phase III clinical trials published until 1 October 2019, evaluating clinical role of tyrosine kinase inhibitors in RCC were retrieved by three different authors (VDN,VM and FM). Keywords used for searching on Pubmed/Medline, Cochrane library, and Scopus, were: "Adjuvant"' OR

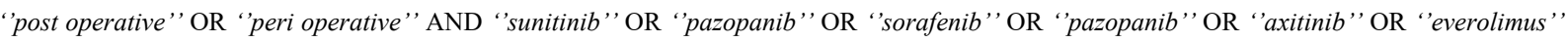
OR “temsirolimus" OR "cabozantinib" OR "lenvatinib" OR "tivozanib" OR 'TKI" OR "tyrosine kinase inhibitors" AND "Renal Cell Carcinoma"' OR 'RCC", OR 'renal tumours" OR " renal carcinoma'; only papers published in peer-reviewed journals, and written in English language, were considered. Furthermore, proceedings of the main International Oncological and Urological meetings (American Society of Clinical Oncology, European Society of Medical Oncology, American Association for Cancer Research, European Association of Urology, and American Urological Association), were also searched from 2005 onwards for relevant abstracts. When more than one report was available describing results of the same trial, the most recent information (corresponding to a longer follow-up and/or a higher number of patients) was considered in the analysis. Studies selected from first analysis were then restricted to clinical trials and then reviewed by three authors (VDN, VM and FM) separately in three different times.

\section{Aims of the meta-analysis}

Aims of the meta-analysis were:

(i) To evaluate the correlation between adjuvant tyrosine kinase inhibitors and Overall Survival (OS) in all patients. For this aim, phase III randomized clinical trials evaluating TKIs impact on OS were eligible.

(ii) To evaluate the correlation between adjuvant tyrosine kinase inhibitors and Disease Free Survival (DFS) in all patients. For this aim, phase III randomized clinical trials evaluating TKIs impact on DFS were eligible.

\section{Data extraction and synthesis}

The following data were extracted for each publication: (a) study; (b) stage; (c) percentages of patients with clear cell or non clear cells tumours; (d) risk staging system adopted; (e) experimental treatment and comparator arm; (f) dosage of experimental drugs; (g) percentage of patients who experienced dose reduction; (h) number of patients; (i) OS and DFS outcome expressed as HR for patients treated with tyrosine kinase inhibitors compared to placebo comparator arm.

In addiction we collected all risk staging system adopted specifying which were the categories of risk considered and the percentage of patients in each risk categories.

Three separate Authors (VDN, VM and FM) conducted the search and identification independently in three different times.

\section{Statistical design}

Co-primary endpoints of the meta-analysis were OS and DFS in all patients. 
Meta-analysis was performed using the Review Manager (RevMan 5.3) software. Summary measure was HR with $95 \%$ CI for OS and DFS. HRs selected for analysis were adjusted for the maximum number of covariates. We applied the inverse variance technique for the meta-analysis of the HRs.. Statistical heterogeneity between studies was examined using the $\chi^{2}$ test and the $\mathrm{I}^{2}$ statistic. 